\title{
BIOFUEL CHARACTERIZATION AND PYROLYSIS KINETICS OF ACACIA MANGIUM
}

\author{
Bemgba Nyakuma ${ }^{1}{ }^{*}$, Olagoke Oladokun ${ }^{1}$
}

https:

\begin{abstract}
The study seeks to proffer practical solutions to the sustainable waste management of Acacia mangium leaves (AML) and explore its solid biofuel (SBF) potential through thermochemical valorization. Consequently, the physicochemical, thermal and kinetic properties of AML were examined using elemental, proximate, bomb calorimetric, thermogravimetric (TG-DTG), and Kissinger kinetic analyses. The results revealed AML possesses high content of carbon, volatile matter, and fixed carbon but low moisture and ash content. The heating value of AML was compared to that of A. mangium wood. Furthermore, thermal decomposition was strongly influenced by temperature and heating rate, although results indicate higher temperatures are required for complete conversion of AML. The Kissinger kinetic model revealed activation energy $E$ and frequency factor $A$ for AML. The results indicate AML possesses good SBF qualities for future bioenergy applications.
\end{abstract}

Keywords: biofuel, pyrolysis, kinetics, Acacia mangium, thermogravimetry.

\section{Introduction}

Acacia mangium is a fast growing, single stemmed evergreen tree shrub of the height of 25-35 m, native to the tropical lowland areas of Indonesia, Papua New Guinea, and Australia. It is denoted by several names, notably Sabah salwood, Black wattle, Tonge hutan, mange hutan, mangium due to its proliferation as exotic species globally. It is also a valuable source of pulp, paper, timber wood, and tannins. In Malaysia, A. mangium is exploited for erosion abatement, soil conservation ( $\mathrm{N}_{2}$ fixation), and roadside trees in urban forestry. It is used for the reforestation of large forest areas degraded by shifting agriculture and uncontrolled logging. However, its high rate of above ground biomass comprising $8.94 \mathrm{t} \cdot \mathrm{ha}^{-1} \cdot \mathrm{yr}^{-1}$

\footnotetext{
${ }^{1}$ Institute of Future Energy, Centre for Hydrogen Energy, Universiti Teknologi Malaysia,

81310 UTM Skudai, Johor Bahru, Malaysia

*bbnyax1@gmail.com

(c) Nyakuma B., Oladokun O., 2017
}

of accumulated leaf litter (LLA) presents considerable waste management challenges [1-5].

Current waste management techniques for A. mangium leaves (AML) involve open burning, incineration and landfilling. The inefficiency and unsustainability of current strategies will potentially exacerbate greenhouse gases (GHGs) emissions and climate change which pose significant risk to human health, safety and the environment. In addition, the selfignition of AML in plantations in the dry seasons can result in forest fires, which emit significant toxic fumes and particulate matter damaging air quality and loss of biodiversity [6-8]. In order to address the aggravating effects of these impending socio-economic and environmental challenges, more efficient techniques for the utilization of agroforestry wastes are urgently required. The lignocellulosic nature of AML presents opportunities for valorization into clean, renewable and sustainable bioenergy and biofuels. The torrefaction, pyrolysis, gasification and combustion can potentially address the challenges of AML waste disposal and management.

However, research on the solid biofuel (SBF) properties and bioenergy potential of AML for thermochemical conversion through biomass conversion technologies is lacking. This is vital data required by academics, engineers, and policy makers to plan, design, and implement future bioenergy and biofuel systems. Consequently, it is imperative to examine, identify and highlight the SBF properties of AML through physicochemical and thermokinetic characterization. Various research groups have examined the SBF of various biomass feedstock such as forest wood [9], agricultural waste [10], and sewage sludge [11] through the characterization techniques elemental, proximate, bomb calorimetry and thermogravimetric analyses [12, 13]. The elemental, proximate, bomb calorimetry provides data for process engineering and reactor design [14] whereas the use of combined thermogravimetric and derivative thermogravimetric analyses presents insights into the thermal stability and decomposition behaviorial properties of materials [15-19]. 
Therefore, this study aims to examine the SBF properties of AML and explore its bioenergy potential for thermochemical conversion under pyrolysis conditions. The study will present results from the characterization of AML using elemental composition, proximate analysis, and bomb calorimetry. The thermal degradation behavior and kinetic decomposition of AML will be investigated using thermogravimetric (TG) and derivative thermogravimetric (DTG) analyses for parametric kinetic analysis using the Kissinger model.

\section{Experimental}

\section{1. $M$ aterials and Methods}

Dried Acacia mangium leaves (AML) were collected from the vicinity of Universiti Teknologi Malaysia, Johor Bahru, Malaysia. The leaves were subsequently pulverized in a dry miller (ELBA EBL9183) and sifted using the Retsch ${ }^{\mathrm{TM}}$ analytical (Mesh size 60) to obtain particles below $250 \mu \mathrm{m}$. Next, the pulverized AML was characterized by ultimate analysis according to ASTM D5291 standard using the vario EL MACRO cube (Elementar Analysensysteme $\mathrm{GmbH}$ ) $\mathrm{CHNS} / \mathrm{O}$ elemental analyzer. The proximate analysis was examined using the ASTM Standards D3173-75 for determining the moisture, volatile matter and ash content while fixed carbon was determined by difference. Higher heating value (HHV) was determined by bomb calorimetry using the IKA C2000 adiabatic bomb calorimeter according to ASTM D2015-85 procedure. Each test was repeated at least three times to ensure the reliability of the measurements.

The thermal decomposition behavior was subsequently analyzed using the Netzsch 209 F3 Tarsus ${ }^{\circledR}$ Thermogravimetric (TG) analyzer. For each run, approximately $8 \mathrm{mg}$ of pulverized AML was placed in an aluminum crucible and heated from 303 to $1073 \mathrm{~K}$ and heating rates of 5,10 , and $20 \mathrm{~K} / \mathrm{min}$ using nitrogen as purge gas. The TG data was subsequently analyzed using the Netzsch Proteus v6.1 TG software.

\subsection{Kissinger Kinetic Model}

The kinetics of AML decomposition was evaluated using the Kissinger model to determine the parameters activation energy $E$ and frequency factor $A$. The pyrolysis decomposition of the biomass AML can be represented by the generic equation [20,21]:

$$
\text { Biomass } \stackrel{k(T)}{\longrightarrow} \text { Volatiles }+ \text { Char }
$$

The volatiles component represents the liquid and gaseous products of biomass pyrolysis. The term $k(T)$ is defined as the rate constant dependent on temperature as expressed in the Arrhenius law:

$$
k(T)=A \exp \left(-\frac{E}{R T}\right)
$$

where $E, A, R$ and $T$ signify activation energy, frequency factor, universal gas constant, and temperature, respectively, used to evaluate the models for AML pyrolysis at $\alpha$ conversions during thermal analysis. Hence the reaction model $[f(\alpha)]$ for the decomposition of AML during pyrolysis can be expressed as:

$$
\frac{d \alpha}{f(\alpha)}=k(T) d t
$$

By substituting Eq. (2) into Eq. (3) the reaction model for the pyrolysis of AML can be deduced as:

$$
\frac{d \alpha}{f(\alpha)}=A \exp \left(-\frac{E}{R T}\right) d t
$$

For AML pyrolysis at different heating rates, the term $\beta$, can be introduced. Hence Eq. 4 can be re-written as:

$$
\frac{d \alpha}{f(\alpha)}=\frac{A}{\beta} \exp \left(-\frac{E}{R T}\right) d T
$$

By integrating Eq. (5) the conversion function $g(\alpha)$ which describes the thermokinetic decomposition of thermal degrading biomass such as AML at a specified heating rate can be obtained:

$$
g(\alpha)=\int_{0}^{\alpha} \frac{d \alpha}{f(\alpha)}=\frac{A}{\beta} \int_{0}^{T} \exp \left(-\frac{E}{R T}\right) d T
$$

This is the essential equation for evaluating the kinetic decomposition of biomasses such as AML and estimating the activation energy $E$, and frequency factor $A$ during pyrolysis. The solution to the equation gives rise to the Kissinger model presented in Eq. (7) [20, 22].

$$
\ln \left(\frac{\beta}{T_{m}^{2}}\right)=\ln \left(\frac{A R}{E}\right)-\left(\frac{E}{R T_{m}}\right)
$$

where $T_{m}$ is defined as the peak or maximum decomposition temperature deduced from the derivative thermogravimetric (DTG) curve. The model can be subsequently used to estimate $E$ and $A$, of AML pyrolysis from the plot of $\ln \left(\beta / T^{2}{ }_{m}\right)$ against $1 / \mathrm{T}_{m}$ at different heating rates.

\section{Results and Discussion}

\subsection{Physicochemical Properties}

The thermochemical fuel properties of AML are presented in Table 1 , where $\mathrm{C}, \mathrm{H}, \mathrm{N}, \mathrm{S}, \mathrm{O}$ represents carbon, hydrogen, nitrogen, sulphur, and oxygen, while $M$, $V M, A$, and $F C$ denote moisture, volatile matter, ash and fixed carbon. 
Thermochemical fuel properties of Acacia mangium

\begin{tabular}{|l|c|c|}
\hline \multicolumn{1}{|c|}{ Elemental Property } & Symbol & Value (wt. \%) \\
\hline Carbon & $\mathrm{C}$ & 51.86 \\
\hline Hydrogen & $\mathrm{H}$ & 6.61 \\
\hline Nitrogen & $\mathrm{N}$ & 1.63 \\
\hline Sulfur & $\mathrm{S}$ & 3.06 \\
\hline Oxygen & $\mathrm{O}$ & 38.84 \\
\hline Moisture & $\mathrm{M}$ & 7.93 \\
\hline Volatiles & $\mathrm{VM}$ & 2.06 \\
\hline Ash & $\mathrm{A}$ & 2.51 \\
\hline Fixed carbon & FC & 17.1 \\
\hline Heating value, $\mathrm{MJ} / \mathrm{kg}$ & HHV & 21.12 \\
\hline
\end{tabular}

The results demonstrate that AML possesses high $C$, $V M, F C$ along with low $M$ and $A$ contents. The low $M$ content theoretically eliminates the need for drying prior to thermal conversion while the low ash content decreases susceptibility to slagging and agglomeration [23]. However, the high $\mathrm{N}$ and $\mathrm{S}$ content $(>1.0)$ of AML potentially present technical challenges due to the tendency for $\mathrm{NO}_{\mathrm{x}}$ and $\mathrm{SO}_{\mathrm{x}}$ emissions. This indicates that the utilization of AML will require pretreatment to lower the $\mathrm{N}$ and $\mathrm{S}$ content in order to improve its environmental friendliness before conversion.

The higher heating value $(H H V)$ of AML was $21.12 \mathrm{MJ} / \mathrm{kg}$, which is higher than A. mangium wood $H H V=20.58 \mathrm{MJ} / \mathrm{kg}$ [1], walnut shell [24], oil palm waste [25], and polar wood [26]. The physicochemical characterization suggests that AML can be potentially utilized as a renewable and sustainable solid biofuel (SBF) for future bioenergy applications in Malaysia.

\subsection{Thermal Analysis}

Fig. 1 presents the thermal degradation behavior of AML examined under pyrolysis conditions. The labels ACM-5, ACM-10 and ACM-20 represent thermal analysis of AML at 5, 10 and $20 \mathrm{~K} / \mathrm{min}$, respectively. The TG curves show the typical downward sloping weight loss indicating the influence of temperature on the thermal decomposition of AML [27]. Furthermore, it can be observed that the TG curves shifted to higher temperatures with increase in heating rate resulting in changes in the temperature profiles of AML $[28,29]$.

Consequently, the onset temperature of decomposition $T_{\text {onset }}$ increased from 524.80 to $543.30 \mathrm{~K}$ with the increase in heating rate. Similarly, the burnout temperature $T_{\text {burnout }}$ increased from 665.70 to $698 \mathrm{~K}$. The effect of heating rate was also observed in the residual mass, which measures potential biochar formation, during pyrolysis. The amount of residual char decreased from 21.68 to $19.10 \%$ with increased heating rate.
Consequently, this indicates that variation in heating rate significantly influenced the devolatization profile valuable in optimizing the product yield of AML pyrolysis. Therefore, the pyrolysis of AML at heating rates of $5 \mathrm{~K} / \mathrm{min}$ or lower will produce higher yield of char whereas heating rates above $20 \mathrm{~K} / \mathrm{min}$ will potentially yield more liquid/gas fuels than char.

\subsection{Derivative Thermal Analysis}

Fig. 2 presents the DTG curves for the pyrolysis of AML during TGA. Likewise, the effect of heating rate and temperature was evident on the profile of the DTG curves. This indicates that although the varying heating rate causes a shift in the TG curves to higher temperatures and enlargement of DTG, the mechanism of degradation is unaffected as illustrated by the shape of the curves in Fig. 2. In addition, the DTG analysis revealed two sets of peaks for each heating rate examined.

The smaller peaks occurred from $303-423 \mathrm{~K}$ while the large peaks ranged from $423-823 \mathrm{~K}$. The difference between the peaks clearly established that AML pyrolysis occurred in three stages: drying (303-423 K), devolatization $(423-823 \mathrm{~K})$ and $(823-1073 \mathrm{~K})$ for char degradation. Similar results have been reported for other biomasses $[19,26]$.

As can be observed in Fig. 2, the drying stage was characterized by smaller peaks with weight loss equivalent to the moisture content of AML. The larger peaks identified between $423-823 \mathrm{~K}$ signify weight loss due to the devolatization of biomass components cellulose and hemicellulose. In addition, the large peaks were characterized by a small "shoulder peak" typically attributed to the presence of hemicellulose in biomass [30]. The aptly termed "hemicellulose shoulder" for AML pyrolysis was identified at 546,553 and $559 \mathrm{~K}$ at 5,10 , $20 \mathrm{~K} / \mathrm{min}$, respectively. The effect of changing heating rate on the devolatization profile of AML analyzed from the DTG curves is presented in Table 2. 


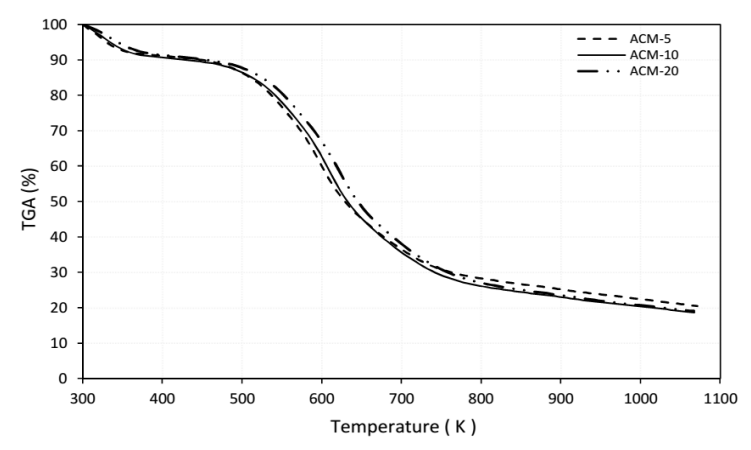

Fig. 1. TG plots for AML

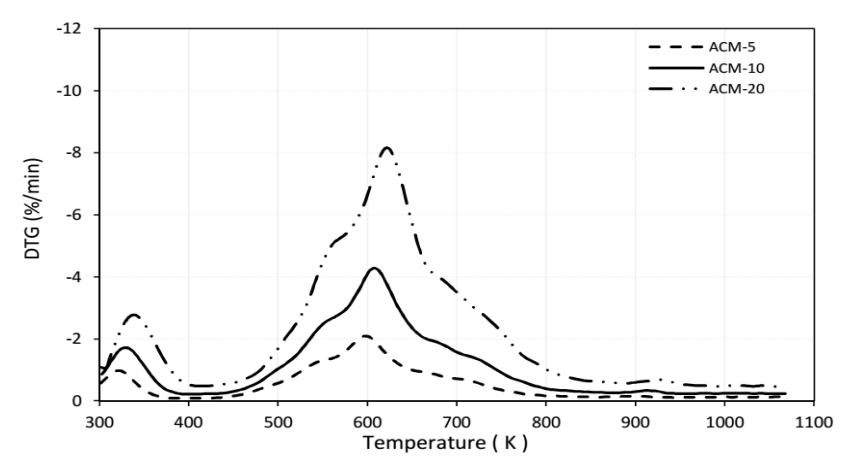

Fig. 2. DTG plots for AML

Table 2

Temperature profile characteristics of AML

\begin{tabular}{|c|c|c|c|}
\hline Heating rate, K/min & Peak decomposition temperature, K & Weight loss rate (WLR), \%/min & Residual mass of AML, \% \\
\hline 5 & 597.50 & 2.12 & 21.68 \\
\hline 10 & 607.50 & 4.29 & 18.62 \\
\hline 20 & 621.10 & 8.17 & 19.10 \\
\hline
\end{tabular}

From Table 2 we can observe that the peak decomposition temperature $T_{m}$, which describes the temperature at which maximum weight loss occurs during pyrolysis, increased with increase in heating rate. The $T_{m}$ values increased within the range of $597.50-621.10 \mathrm{~K}$ due to the shift in DTG curves caused by the thermal-time lag, which occurs with change in heating rate $[26,28]$. Similarly, the weight loss rate noticeably doubled when the heating rate increased by a factor of two.

\subsection{Kissinger Kinetic Analysis}

Fig. 3 presents the Kissinger kinetic plots for AML obtained by plotting $\ln \beta / T_{m}{ }^{2} v s .1 / T_{m}$ at different heating rates. The kinetic parameters $E$ and $A$ were calculated from the slope and intercept of line plot.

Consequently, the $E$ and $A$ values for AML pyrolysis during TGA were calculated from the values of the slope and intercept of the equation $y=-20.291 x+22.819$. Consequently, the kinetic parameters were deduced as $E=168.70 \mathrm{~kJ} / \mathrm{mol}$ and $A=1.65 \cdot 10^{11} \mathrm{~min}^{-1}$ with the coefficient of correlation $R^{2}=0.9943$. In comparison, the values of $E$ for other biomasses using the Kissinger model were $E=209.75 \mathrm{~kJ} / \mathrm{mol}$ for tea waste [20] and $E=153.92 \mathrm{~kJ} / \mathrm{mol}$ for poplar wood [26]. Hence the comparatively lower $E$ values indicated that the pyrolysis of AML is faster than that of tea waste but slower than of poplar wood. Overall, the thermal and kinetic properties of AML make it potentially viable solid biofuel (SBF) feedstock for future bioenergy applications.

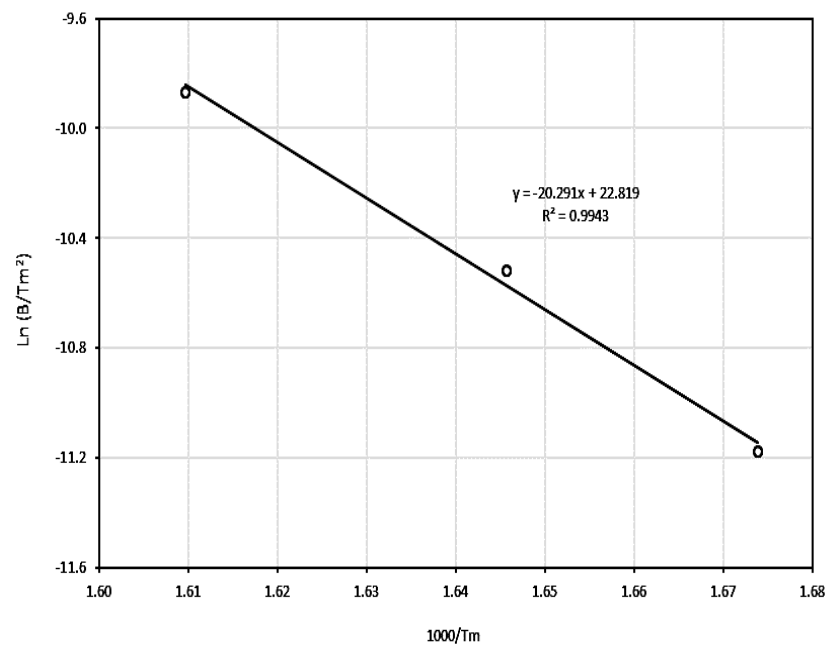

Fig. 3. Kissinger kinetic plot for $\mathrm{AML}$

\section{Conclusions}

The solid biofuel (SBF) bioenergy potential of Acacia mangium leaves (AML) was examined by characterizing physicochemical, thermal and kinetic properties under pyrolysis conditions. The results indicate that AML contains sufficient elemental and calorific content for potential conversion into clean, renewable and sustainable bioenergy fuels for the future. In addition, the low ash and moisture content of AML highlights its low susceptibility to slagging and agglomeration during biomass conversion. However, thermal analysis revealed that AML will require temperatures above $1073 \mathrm{~K}$ to accomplish complete pyrolysis into solid, liquid or gaseous biofuels. 


\section{Acknowledgments}

The authors gratefully acknowledge the financial and material support of Centre for Hydrogen Energy, Institute of Future Energy, and Energy Research Alliance of Universiti Teknologi Malaysia (UTM). The kind assistance of Mr Wong Syie Luing of Faculty of Chemical Engineering Universiti Teknologi Malaysia and Muhamad Faizal B.A. Halim of the Centre of Polymer Composites Research \& Technology (PoCResT), Universiti Teknologi MARA is also recognized.

\section{References}

[1] Orwa C., Mutua A., Kindt R. et al.: Acacia mangium. Agroforestree database: a tree reference and selection guide version 4.0, http://bit.ly/1NiAVfF.

[2] Mat S., Ab-Shukor N.-A., Hamzah M.-Z. et al.: J. Agricult. Sci., $2009,1,74$

[3] Ilstedt U., Malmer A., Nordgren A., Liau P.: Forest Ecol. Manag., 2004, 194, 215. https://doi.org/10.1016/j.foreco.2004.02.032

[4] Tsai L.: J. Trop. Ecol., 1988, 4, 293. https://doi.org/10.1017/S0266467400002856

[5] Cetinkol O., Smith-Moritz A., Cheng G et al.: PLoS One, 2012, 7, e52820. https://doi.org/10.1371/journal.pone.0052820

[6] Nasi R., Meijaard E., Applegate G, Moore P.: Unasylva, 2002, 53, 209.

[7] Page S., Siegert F., Rieley J. et al.: Nature, 2002, 420, 61. https://doi.org/10.1038/nature01131

[8] Herawati H., Santoso H.: Forest Policy Econom., 2011, 13, 227. https://doi.org/10.1016/j.forpol.2011.02.006

[9] Brostow W., Menard K., Menard N.: Chem. Chem. Technol., 2009, 3, 173.

[10] Nyakuma B.: Environ. Climate Technol., 2015, 15, 77.

[11] Magdziarz A., Werle S.: Waste Manag., 2014, 34, 174. https://doi.org/10.1016/j.wasman.2013.10.033

[12] Viana H., Vega-Nieva D., Torres L. et al.: Fuel, 2012, 102, 737. https://doi.org/10.1016/j.fuel.2012.06.035

[13] Serapiglia M., Cameron K., Stipanovic A., Smart L.: Appl. Biochem. Biotech., 2008, 145, 3. https://doi.org/10.1007/s12010007-8061-7

[14] Johari A., Nyakuma B., Ahmad A. et al.: Appl. Mech. Mat., 2014, 493, 3.

[15] Brostow W., Datashvili T.: Chem. Chem. Technol., 2008, 2, 27. [16] Nyakuma B., Mazangi M., Johari A. et al.: 2014. MATEC Web of Conferences. EDP Sciences 2014.

[17] Park J.-K., Lee W.-B., Park Y.-S. et al.: Chem. Chem. Technol., 2013, 7, 405.

[18] Ramos M., Beltran A., Valdes A. et al.: Chem. Chem. Technol., 2013, 7, 295.
[19] Nyakuma B., Johari A., Ahmad A., Abdullah T.: Jurnal Teknologi, 2014, 67, 3. https://doi.org/10.11113/jt.v67.2768

[20] Polat S., Apaydin-Varol E., Putun A.: J. Selcuk Univ. Nat. Appl. Sci., 2013, 420.

[21] Basu P.: Biomass Gasification, Pyrolysis and Torrefaction: Practical Design and Theory. Academic Press 2013.

[22] Ledakowicz S., Stolarek P.: Chem. Pap., 2002, 56, 378.

[23] Basu P.: Combustion and Gasification in Fluidized Beds. CRC Press 2006. https://doi.org/10.1201/9781420005158

[24] Acıkalin K.: J. Therm. Anal. Calorim., 2011, 105, 145. https://doi.org/10.1007/s10973-010-1267-x

[25] Nyakuma B., Johari A., Ahmad A.: J. Appl. Sci., 2012, 12, 2527. https://doi.org/10.3923/jas.2012.2527.2533

[26] Slopiecka K., Bartocci P., Fantozzi F.: Appl. Energ., 2012, 97, 491. https://doi.org/10.1016/j.apenergy.2011.12.056

[27] Oladokun O., Ahmad A., Abdullah T. et al.: Chem. Eng. Transact., 2015, 45, 919. https://doi.org/10.3303/CET1545154

[28] Damartzis T., Vamvuka D., Sfakiotakis S., Zabaniotou A.: Biores. Technol., 2011, 102, 6230. https://doi.org/10.1016/ j.biortech.2011.02.060

[29] Nyakuma B., Ahmad A., Johari A. et al.: Chem. Eng. Transact., 2015, 45, 1327. https://doi.org/10.3303/CET1545222

[30] Joshi Y., Di Marcello M., de Jong W.: J. Anal. Appl. Pyrol., 2015, 115, 353. https://doi.org/10.1016/j.jaap.2015.08.014

Received: April 07, 2016 / Revised: M ay 15, 2016 / Accepted: December 27, 2016

\section{БІОПАЛИВНА ХАРАКТЕРИСТИКА ТА КІНЕТИКА ПІРОЛІЗУ АКАЩЇ МАНГІУМ (ACACIA MANGIUM)}

Анотація. Запропоновані практичні рімення для утилізації листя акації мангіум (ЛАМ) $i$ за допомогою термохімічної валоризації встановлено його потенціал як твердого біопалива. 3 використанням елементарного, технічного, калориметричного, термогравіметричного аналізів та методу Кіссінджера досліджені фізико-хімічні, теплові та кінетичні властивості ЛАМ. Показано, що ЛАМ має високий вміст карбону, леткість $i$ вміст зв'язаного карбону, але відносно низький вологовміст $i$ зольність. Визначена теплотворна здатність ЛАМ є вищою у порівнянні з величиною для A. mangiuт деревини. Крім того, термічний розклад суттєво залежить від температури $i$ швидкості нагріву, хоча результати вказують на необхідність вищих температур для повного перетворення ЛАМ. За допомогою кінетичної моделі Кіссінджсера визначено енергію активації Е і фактор частоти А. Показано, щчо ЛАМ має задовільні біопаливні характеристики і може застосовуватись у біоенергетииі.

Ключові слова: біопаливо, піроліз, кінетика, акація мангіум, термогравіметрія. 